\title{
A framework for assessing coupling and de-coupling trajectories in river social-ecological systems
}

\author{
Cristina Quintas-Soriano ${ }^{1,2,3}$ - Jodi Brandt ${ }^{4} \cdot$ Colden V. Baxter $^{2} \cdot$ Elena M. Bennett ${ }^{5} \cdot$ Juan Miguel Requena-Mullor $^{6}$. \\ Antonio J. Castro ${ }^{1,2}$
}

Received: 8 February 2021 / Accepted: 16 September 2021 / Published online: 11 October 2021

(c) The Author(s) 2021

\begin{abstract}
The degree of coupling between the social and ecological components of social-ecological systems is seen as fundamental to understanding their functioning, interactions and trajectories. Yet, there is limited work about how to empirically understand the degree of coupling between social and ecological systems, nor the processes by which the degree of coupling could change over time. Here, we introduce a conceptual framework for characterizing trajectories over time of coupling and de-coupling in social-ecological river systems. We analyze two conceptual scenarios describing coupling and de-coupling trajectories in a social-ecological system and define a series of key concepts for understanding social-ecological system trajectories. We tested these coupling and de-coupling trajectories theory by linking these concepts to empirical case examples of two river social-ecological systems in the western United States. Finally, we propose a quantitative approach with the potential for evaluating the level of social-ecological coupling and de-coupling trajectories in other SES contexts. This paper represents an advancing on the identification of specific actions that explain current SES trajectories and immediate actions to reinforce or shift the trajectory.
\end{abstract}

Keywords Complex adaptive systems · Feedback · Governance $\cdot$ Idaho $\cdot$ Land use trajectory $\cdot$ Social-ecological resilience $\cdot$ Vulnerability

Handled by Rajarshi Das Gupta, Institute for Global Environment Strategies Natural Resource and Ecosystems, Tokyo, Japan.

\section{Cristina Quintas-Soriano}

cristina.quintas@ual.es

1 Departamento de Biología Vegetal y Ecología, Centro Andaluz para la Evaluación y Seguimiento de Cambio Global (CAESCG), Universidad de Almería, La Cañada de San Urbano, 04120 Almería, Spain

2 Department of Biological Sciences, Idaho State University, 921 South 8th Avenue, Pocatello, ID 83209, USA

3 Colectivo FRACTAL, San Remigio 2, 28022 Madrid, Spain

4 Human-Environment Systems, Boise State University, Boise, ID, USA

5 Department of Natural Resource Science and McGill School of Environment, McGill University, Montreal, QC, Canada

6 School for Environment and Sustainability, University of Michigan, Ann Arbor, USA

\section{Introduction}

The science of social-ecological systems (SES), which is also variously called human-environment systems (HES) and coupled human-nature systems (CHANS) (Wang et al. 2018), describes a co-evolutionary phenomenon in which ecosystem services are the emergent outcomes of complex interactions and feedbacks between social and ecological components of a system (Berkes and Folke 2000; Liu et al. 2007a; Reyers and Selomane 2018). While the ecosystem service (ES) framework typically depicts a system in which ES flows start from the ecological system and move towards social ones (Haines-Young and Potschin 2010), SES approaches typically feature back and forth interactions between ecological and social processes (Liu et al. 2007b). The core axiom of SES science is that human and ecological systems are coupled, i.e. they interact and co-evolve over time and have substantial impacts upon one another, with causality operating in both directions (Fischer-Kowalski and Weisz 2016). 
The SES science has had a dramatic influence on interdisciplinary sustainability research globally (Entwisle and Stern 2005). However, a clear consensus as to what defines a "coupled" SES has not been established, and applications with both theoretical and empirical foundations are rare (Chen et al. 2015). Previous SES research has more frequently been focused on the theoretical analysis of SES frameworks (Pulver et al. 2018), land-use change (e.g., Foley et al. 2005; Lambin and Meyfroidt 2011; Meyer and Turner II 1994), SES dynamics (e.g., Alessa et al. 2008; Hoole and Berkes 2010; Chen et al. 2015; Schmitz et al. 2017), vulnerability analysis (Thiault et al. 2018), resilience theory (e.g., Fernández-Giménez et al. 2017; Folke 2006; Walker and Salt 2006) and SES tipping points (Mathias et al. 2020). However, if by definition a SES is a coupled system, is it possible for a SES to be de-coupled? Although most studies in SES literature widely use the concept of coupled SES, there is no agreed definition of what it means to be a coupled SES, and as a consequence the conceptualization and definition of "de-coupled" SES (c.f., Hoole and Berkes 2010) remains as a conceptual gap that has constrained empirical investigation and applications to decision-making in SES.

Here we introduce a conceptual framework for characterizing SES coupling and de-coupling trajectories through time, and apply that framework using a case study of two socio-ecological river systems in the western United States. Rivers are excellent model systems for examining the concept of coupling in SES dynamics because of the historical co-evolution of rivers, including their associated riparian zones, wetlands and floodplains, with human societies in what some have referred to as "riverscapes" (Dunham et al. 2018; Hand et al. 2018; Torgersen et al. 2021). Humans have significantly altered most river ecosystems worldwide because of the dependence on healthy rivers for water, food, and other ecosystem services (Postel and Richter 2012; Yeakley et al. 2016). At the same time, humans dramatically modify river systems through the construction of dams and levees to constrain flooding, and channelization to allow the movement of water to meet social demands for agriculture, energy, navigation or urban development (Benke 1990; Poff et al. 2007; Hand et al. 2018). In addition, land-use changes in river drainage basins alter river ecosystem functions and associated ecosystem services around the world (Döll et al. 2009; Gunderson et al. 2018). Thus, most river systems on earth are human-engineered to meet specific, local societal goals, which has led to ecological regime shifts, affecting ecosystem services provision and promoting different SES outcomes (Yeakley et al. 2016; Dunham et al. 2018).

Using rivers as a model system to increase our understanding of the concepts of "coupling" and "de-coupling" in SES science, this paper: (1) defines key concepts within the SES framework; (2) introduces a conceptual framework focused on SES coupling and de-coupling trajectories that enables empirical assessment of these concepts; and, (3) applies this framework within two river systems in the western United States, with the goal of describing examples of coupling and de-coupling SES trajectories associated with different flooding control strategies. Finally, we discuss the utility of considering SES coupling and de-coupling trajectories not only to help interpret the past and present of rivers and their communities, but also to purposefully guide decisions and behaviors aimed at "re-coupling" or maintaining connections in the face of new challenges.

\section{Key concepts of the SES framework}

Researchers from various disciplines have used the term "coupled SES" for describing any systems in which the human and natural components interact. The term "coupled" has become very popular to define or frame an analysis in recent SES literature, and the explicit investigation of the "couplings", i.e., the reciprocal interactions between linked human and natural systems, has become a key feature of SES research (Liu et al. 2007a, b). However, the terminology lacks a consensual meaning beyond the above general definitions.

We explicitly define common terminology used in SES science as it pertains to the concepts of coupling (Box 1) based on several foundational concepts in the SES literature. First, coupled SES have more adaptive capacity (sensu Folke et al. 2010), and thus are more resilient, than decoupled SES. Resilience is defined as a system's ability to persist amidst major disturbance or to adapt to a disturbance through a reconfiguration of the system and its interactions (Folke et al. 2005, 2010; Walker et al. 2004; Folke 2006). Systems that are not resilient are at risk of experiencing a regime shift, defined as a critical transition in a system's dynamics from one state to a very different one, typically because some process moves the system beyond a tipping point (Bauch et al. 2016). Therefore, we define that a SES is "coupled" based on its adaptive capacity, and resilience. In a coupled SES, humans are more likely to inform, detect and respond to changes in time to pro-actively manage the ecological system to prevent undesirable regime shifts. In a de-coupled SES, information about the linkages between the ecological system and the social system are weak or non-existent, and thus inadequate to ensure that management actions avoid regime shifts. In addition, the term "recoupling" has emerged to describe a de-coupled system that has recovered interactions between the ecological and social systems (Hoole and Berkes 2010), a process that, as we understand it, typically requires active intervention (Berkes and Folke 2000; Armitage et al. 2007). In this context, we understand that "re-coupling" implies that a SES can be returned to a precise previous state of the system. 
Box 1 Key definitions of the SES framework

Key social-ecological systems concepts

Coupled SES

A SES where informational feedbacks between the social and ecological systems influence the capacity of the system to adapt to external drivers, such that human communities can pro-actively manage the coupled system to prevent undesirable SES outcomes. A coupled SES leads to beneficial SES outcomes (i.e., ecosystem services and human well-being)

De-coupled SES

A SES where informational feedbacks between the social and ecological systems influence the capacity of the system to avoid adapting to external drivers of change, such that human communities cannot proactively manage the system to prevent undesirable SES outcomes. A decoupled SES leads to unfavorable SES outcomes

Re-coupled SES

A de-coupled system that transforms to a coupled system

Feedback loop

Informational flows regarding specific anthropogenic inputs such as changes of labor, technology, or energy, with the capacity of influencing coupling and/or de-coupling trajectories

Coupling trajectory

Transition process by which the feedbacks within the SES increase the adaptive capacity of the SES through time and thereby lead to a more coupled SES

De-coupling trajectory

Transition process by which the feedbacks within the SES lead to less adaptive capacity of the SES through time and thereby to a more decoupled SES

The definitions above allude to coupling in terms of responses of a SES to external factors driving system change (e.g., management decisions). However, the importance of "feedback loops" intrinsic to the SES are also well established (Folke et al. 2010; Walker et al. 2004). Therefore, to our definitions of coupled and de-coupled, we add the concept of feedbacks. In coupled systems, the feedbacks between systems (i.e., ecological and social) are tightly linked and enable learning and adaptation (Walker and Salt 2006; Fernández-Giménez et al. 2017). The loss of such tightly-linked interactions between systems lead to "de-coupling," so systems may change independently over time (Hoole and Berkes 2010). Feedbacks between the two systems exist continuously, however, the informational flows associated with feedbacks are crucial to understanding changes between systems. In this sense, the informational flows that reach the local public may occur in different directions, or not at all. Therefore, we define feedback loops as existing informational flows regarding specific anthropogenic inputs such as changes of labor, technology, or energy with the capacity of influencing coupling and/or de-coupling trajectories (Rist et al. 2014). Feedback loops can inform the amplification or dampening of a specific change in a particular direction and lead either to a coupling or de-coupling trajectory (see Box 1). For instance, in the context of management of river and agricultural systems, a feedback loop might occur when information among different river beneficiaries (e.g., farmers and fisherman) produce sustainable water management that satisfies both agriculture and fisheries needs. In this case, the informational flow between social and ecological systems promotes a well-connected SES by simultaneously advocating for good water quality and water needs for agricultural purposes, leading to a coupling SES trajectory. Conversely, a feedback loop may occur when information occurs only in one direction, for instance, the impact that agricultural pesticides have on water quality and aquatic biodiversity. In this occasion, the information flow is limited to one direction whereby local populations use pesticides to control agricultural plagues, but simultaneously promote a negative impact on the water quality of the river, leading to a de-coupling trajectory.

Finally, we introduce here the definitions of coupling and de-coupling trajectories, explicitly acknowledging that a SES, at any given time, is developing towards a more or less coupled state. We define the "coupling trajectory" as that transition process by which the informational feedbacks within the SES lead to more adaptive capacity of the SES through time, and thereby to a more coupled SES. On the other hand, a "de-coupling trajectory" occurs when the informational feedbacks within the SES lead to less adaptive capacity, therefore developing toward a more de-coupled SES. The main utility of acknowledging and investigating coupling and de-coupling trajectories is to: (i) identify trajectories that may have led to the current coupled or de-coupled state of a SES, (ii) evaluate possible methods to encourage re-coupling, or (iii) evaluate methods to preserve that coupling. 


\section{B SES Coupling trajectory}

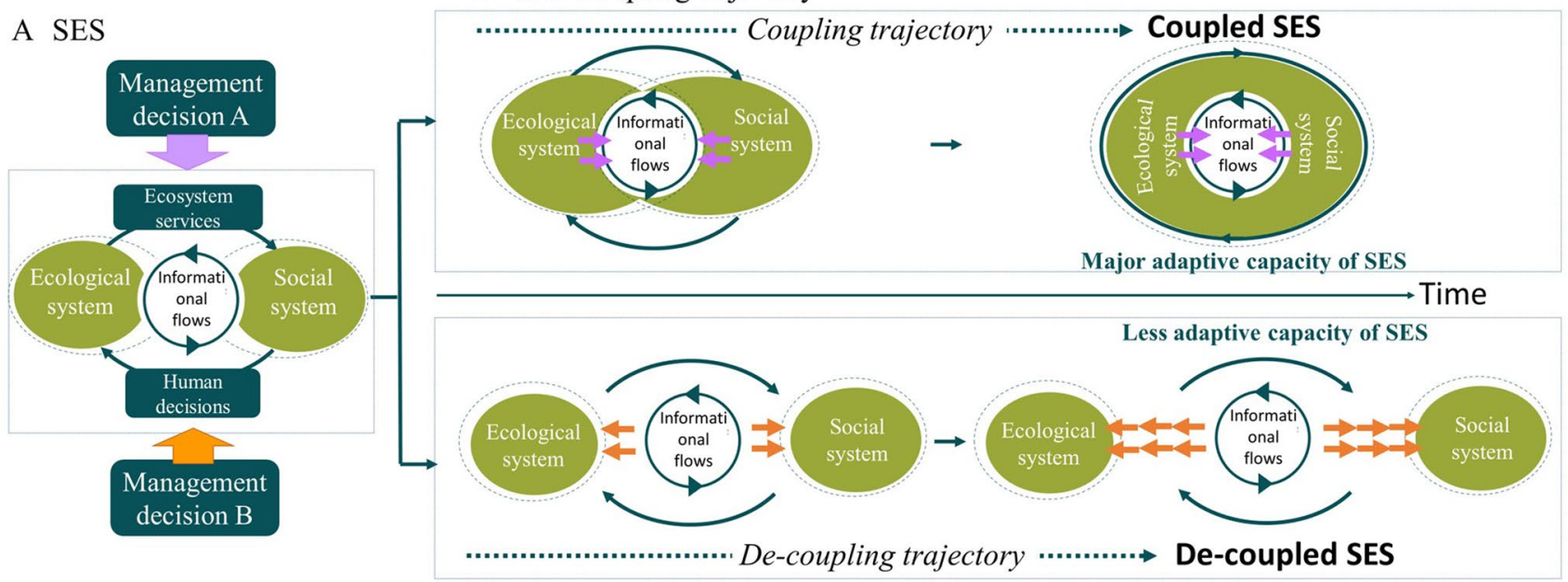

C) SES De-coupling trajectory

Fig. 1 Here we present how the existing SES framework (A) (Resilience Alliance 2007;*** Ostrom 2009) can be adapted to incorporate the temporal dimension of coupling (B) and de-coupling (C) trajectories scenarios over time. In the existing SES framework (A), the ecological and social systems are in light green, and are linked by the dark green arrows, which represent processes in the social system that affect the ecological system (human decisions), and the processes in the ecological system that affect the social system (ecosystem services). Feedback loops are a combination of these interactions, as well as the informational flows between the two systems. These feedback loops serve as the intrinsic mechanisms which tie the

\section{A conceptual framework focused on SES coupling and de-coupling trajectories that enables empirical assessment}

While theoretical developments in SES science have advanced greatly in recent years (see Chapin et al. 2010; Biggs et al. 2012; Holzer et al. 2019), the quantitative integration of the social and ecological systems has remained challenging. There have been some studies considering social approaches that have developed an assessment of partial interactions in SES. For instance, Fernández-Giménez et al. (2017) recently described how declining herder populations in Mongolia could signal the approach of a cultural tipping point. As pastoralism wanes, so does the culture surrounding herding, leading to the loss of identity and traditional knowledge. Their analysis linked a social process to a previous ecological tipping point, but it did not address the concomitant interactions or feedbacks occurring within the SES. Similarly, Hoole and Berkes (2010) found that when communities in northern Namibia were forcibly ousted from their land and became alienated from their traditional territories, a de-coupling process occurred driven by pastoralists' loss of access to a variety of environmental and cultural resources, such as reliable water and forage, ancestral graves, opportunities to gather field foods and medicinal plants, and two systems together. We argue that the SES shown in A is constantly developing, and depending on the strength of the informational flows, a SES can develop either to a coupling trajectory $(\mathbf{B})$ or a de-coupling trajectory $(\mathbf{C})$. In both scenarios, the SES is influenced by external factors (e.g., management decisions). However, in the coupling trajectory the feedbacks serve to more tightly link the systems (as demonstrated by the purple arrows), which further increases SES adaptive capacity. In contrast, in the case of the de-coupling trajectory, the same external drivers may influence the system, but the difference is that the feedbacks serve to make the systems less tightly linked (indicated by the orange arrows)

social memory for traditional rules and community memory. Their analysis demonstrated changes that occurred within the social system as part of a de-coupling process, but did not measure linked changed in the natural system. Building on such contributions, it seems important to more explicitly assess linked feedbacks and interactions within SES.

Integrative attempts to investigate social and ecological systems of SES have arisen from systemic approaches (Norberg and Cumming 2008; Ostrom 2009), whereby both social and ecological values are considered to assess the relationships between the two systems (Fig. 1A). For instance, Alessa et al. (2008) used spatial analysis approaches to define and identify coupled SES as areas where measured social and ecological values converge on the landscape (e.g., hunting in a coastal Alaska region is concentrated in a highly productive forest with a dense moose population). Another approach is the use of quantitative models to predict how different scenarios of social and ecological interactions influence one outcome of interest in the system. For example, Schmitz et al. (2017) described how in the Spanish Fuerteventura island, processes such as 'de-agrarianization' and 'de-ruralization' transformed a coupled local SES in which native inhabitants were linked to the landscape via their traditional land-use practices, to a de-coupled system based on coastal tourism. Such studies have demonstrated 
measures of coupling within SES and illustrate how this connectivity may occur. This naturally leads to questions regarding dynamics of coupling associated with trajectories of SES change (Locatelli et al. 2017; Santos-Martín et al. 2019). We know of no studies that have attempted to explicitly evaluate the trajectory (i.e. direction and magnitude) of coupling. In part, this may be due to the lack of a common framework and a terminology that would allow comparable empirical characterization of SES coupling and de-coupling processes.

Here, we present a conceptual framework (Fig. 1) focused on river SES that explicitly acknowledges (a) the development of SES over time, and (b) the different trajectories that may occur with respect to coupling or de-coupling. Furthermore, our framework enables empirical evaluation of these trajectories. We start with the existing and commonly accepted SES framework (Fig. 1A), and then we present two possible scenarios that evolve from the baseline framework: SES coupling (Fig. 1B) and de-coupling (Fig. 1C) trajectories. Both trajectories represent the processes by which feedbacks within the SES develop and change through time leading to specific SES outcomes (either positive or negative) and to different levels of adaptive capacity of the system. We define the level of SES coupling and de-coupling based on the presence and strength of those feedback loops active in the system that lead to different degrees of adaptive capacity.

\section{Apply the framework to demonstrate the divergent trajectories of two river SES}

We applied our framework using two social-ecological river systems located in the western United States, the Boise and Portneuf Rivers placed in Idaho $(4,100$ square miles and 1,329 square miles, respectively) (Fig. 2). We selected these river systems because are quite similar geographically and ecologically, but different decisions about flood control in
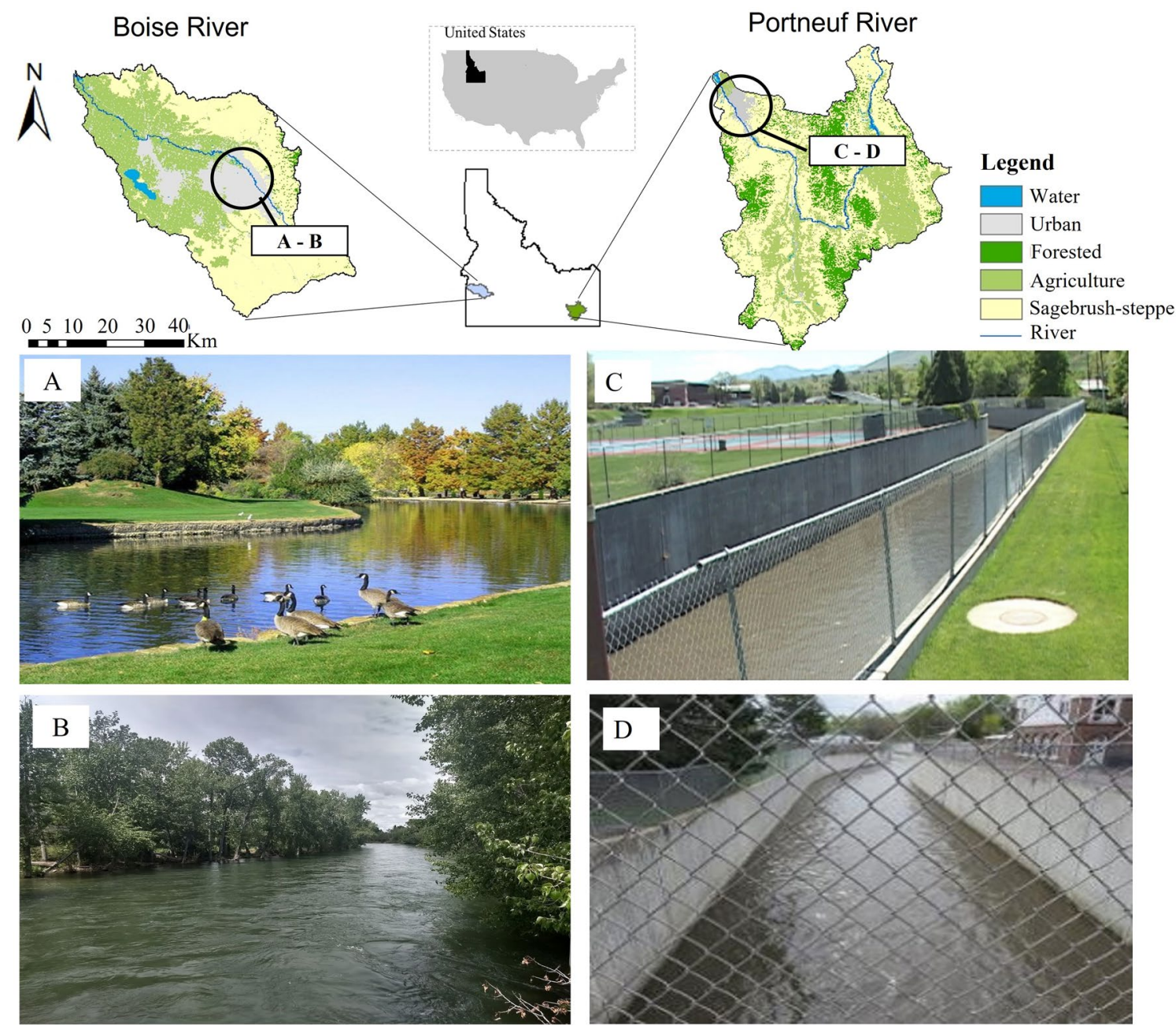

Fig. 2 Map of the two social-ecological river systems: the Boise River located in the Treasure Valley on the left, and Portneuf Valley and the Portneuf River on the right. The two pairs of images are asso-

ciated with the river systems: A the Green Belt in Boise city, $\mathbf{B}$ the Boise River within the city of Boise, $\mathbf{C}$ and $\mathbf{D}$ the channel of the Portneuf River in Pocatello 
the past century produced a coupling trajectory in the Boise River-City of Boise SES, and a de-coupling trajectory in the SES associated with Pocatello and the Portneuf River. These two river systems represent an ideal case study to develop and apply our hypothesis of the social-ecological trajectories. Our analysis is focused on the cities of Boise and Pocatello, their communities and the associated rivers flowing through them.

We collected data for indicators representing the four main components of each social-ecological river system, including indicators to assess (Fig. 3): (i) ecological system, (ii) social system, (iii) ecosystem services as the processes in the ecological system that affect the social system, and (iv) governance as the processes in the social system that affect the ecological system. The rationale behind the selection of the list of indicators was based on previous literature assessing SES components, the availability of data for the same indicators for both sites of study and the proper characterization of each four main components of each social-ecological river system (Supplementary material A).

Data for the ecological system included indicators of water quality, river beneficial uses (i.e., ecosystem services as delineated under the US Federal Clean Water Act) and causes of impairment associated with any loss of these services (IDEQ 2017). The social system was characterized using socio-demographic variables describing the economic capacity, food security, health and freedom, and motivation of the local population (US Bureau of Census or the Bureau of Economic Analysis 2016). These factors were not chosen because we anticipated they were affected by coupling or de-coupling or were drivers of river SES coupling or decoupling. Rather, we expected them to be useful in interpreting observations, as they have the potential to influence, or be influenced by, each community's relationship with their river. To evaluate local perceptions regarding a variety of ecosystem services provided in each watershed, we conducted a survey of over 1000 people (Quintas-Soriano et al. 2018, 2021; Narducci et al. 2019). Responses to some of these survey questions also allowed us to assess cultural or more precisely, "relational" values (sensu Chan et al. 2016) held within each community regarding their river. Finally, to characterize the governance component, we conducted a historical assessment of the last $~ 100$-years of management and governance dynamics associated with each river SES. We identified specific milestones for each river SES and created a timeline to help describe their trajectory. A full description of the indicators used in the analyses are provided in the supplementary material.

\section{Ecological setting, and initial post-European settlement patterns in the Boise and Portneuf Rivers}

Our two case study areas share strong similarities in terms of their environmental conditions. Both rivers are characterized by a semi-arid climate and flow through large floodplain valleys of flat, fertile soils surrounded by less hospitable (to humans) sagebrush steppe and rugged mountains. The two areas also share similar initial post-European contact settlement patterns (see Fig. 4 for the timeline of settlement, population growth, and major management decisions for both rivers).

The original inhabitants of the Boise River valley were the Shoshone, Bannock, and Paiute tribes, and the city of Boise is located on unceded territory of these tribes. It was established along the Boise River in the mid-1800s with the discovery of gold in the surrounding mountains (MacGregor
Fig. 3 Indicators compiled for characterizing coupled and decoupled trajectories in socialecological river systems

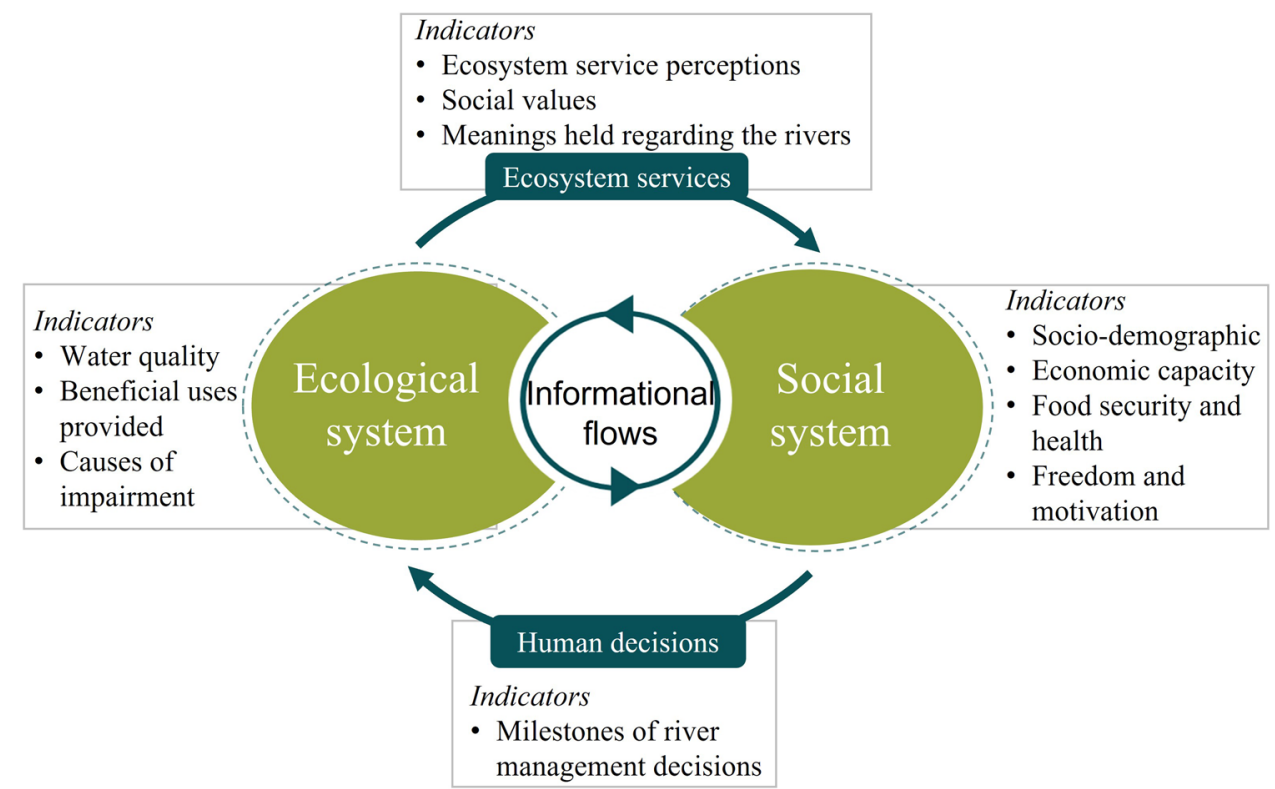




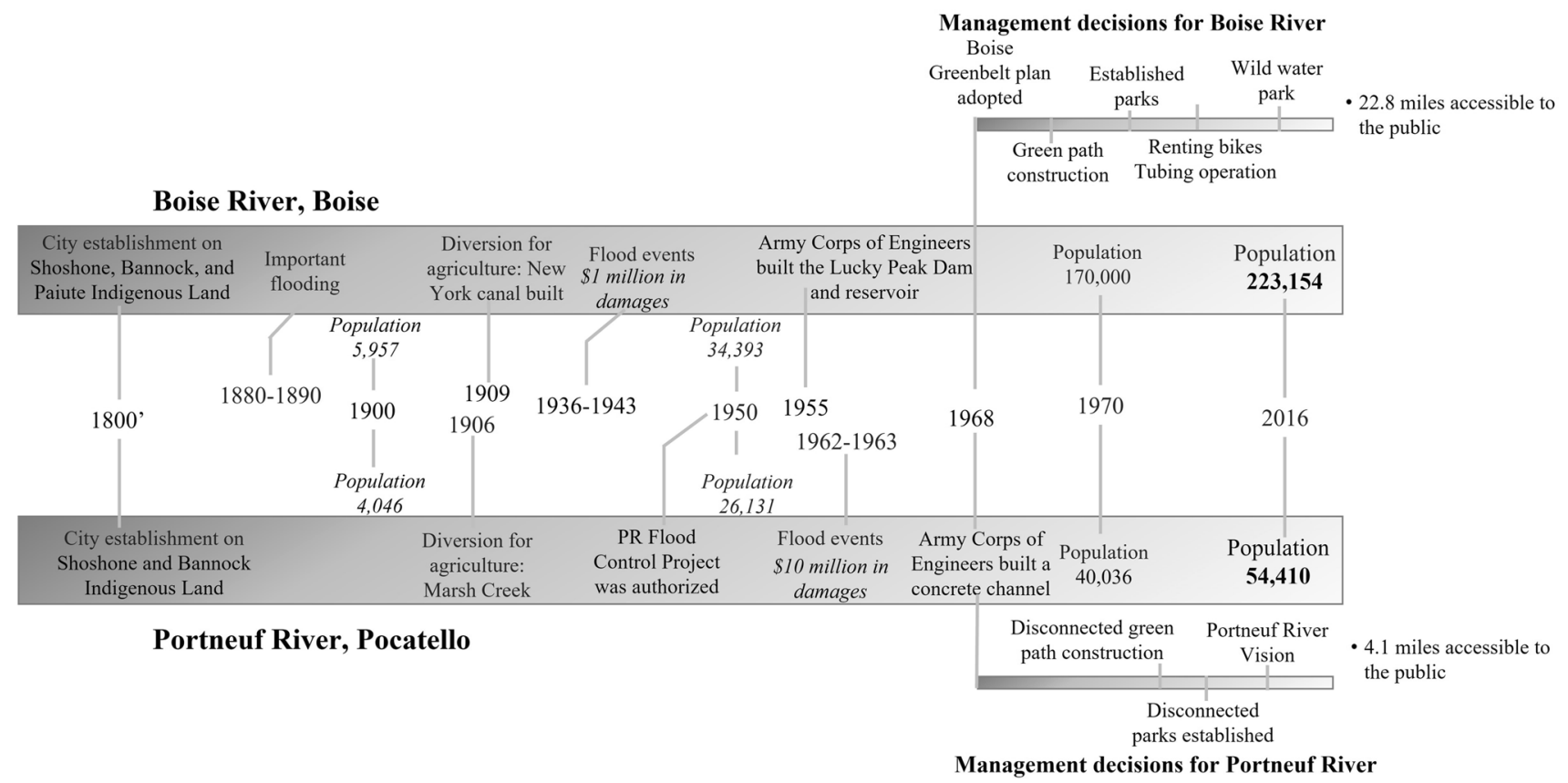

Fig. 4 Storyline and milestones of governance and management decisions in the Boise and Portneuf River

1999). Boise became the territorial capital in 1864, and the first diversion irrigation ditch was constructed in 1863. Over the next several years, small-scale irrigation projects transformed the surrounding sagebrush steppe into agricultural lands, and by 1900, the area became an agricultural hub of the territory, with 148,000 acres of irrigated land, active commerce, and amenities such as electricity, telephone service, and railways. Between 1909 and 1915, the construction of a major dam and canal irrigation system (the New York Canal and Arrowrock Dam) allowed hundreds of thousands more acres to be converted to irrigated agriculture (MacGregor 1999; Fig. 4). In the 1950s, industrial development proliferated along the Boise River, leading to a variety of water quality issues, including severe contamination derived from waste from food processing plants and domestic sewage, declining trout populations, silt deposition, bacterial slimes, algae blooms, and high bacteria levels. In 1950, the human population was 34,393.

Similar to Boise, the original inhabitants of the Portneuf River valley were the Shoshone and Bannock tribes. Indeed, the city of Pocatello itself is located on lands that were part of the original reservation of the Shoshone-Bannock Tribes but that were subsequently carved out of the reservation by an 1888 Act of Congress in response to railroad development and associated settler demands for land (Murphy and Murphy 1960). The City of Pocatello was founded along the Portneuf River in 1892 and became a railroad hub. As occurred for the Boise River, by 1912 a small storage reservoir and irrigation diversion canal had been constructed along the Portneuf River upstream of Pocatello. Outside of
Pocatello, the floodplain was converted to irrigated agriculture, while within Pocatello, house lots and streets were laid out in a grid parallel to the railroad tracks and the river such that undeveloped lands were not reserved for floodplain. By the mid-twentieth century, the Portneuf River had been straightened in several locations to reduce flooding and to make room for development, croplands and grazing impacts had increased in the watershed leading to sediment pollution of the river, and a number of industries that had grown along the river contributed point sources of pollution (Link and Phoenix 1994). This, combined with non-point sources of both urban and agriculture, led to the Portneuf's characterization as a polluted river by the 1960s (Minshall and Andrews 1973). In 1950, the human population was 26,131 (Fig. 4).

\section{Flood control decisions on the Boise and Portneuf Rivers lead to divergent SES trajectories}

In the mid-twentieth century, the two case study areas had a similar population, land use, and river contamination conditions. However, severe flooding events that occurred in both rivers triggered two very different flood control strategies in each river, which contributed to divergent SES trajectories.

In the case of the Boise River, the need for flood control (along with irrigation and hydroelectricity demands) led to two additional massive dams being constructed upstream of the city (in 1950 and 1955) (Jaussaud 1994). Whereas these dams severed various forms of riverine connectivity at the scale of the entire watershed (e.g., passage was lost 
for fishes such as anadromous salmon and steelhead), within the city of Boise a result was that the capacity was retained for maintaining or restoring a more natural riparian zone and extensive public access along the river (Jaussaud 1994). In addition, the river water entering Boise tended to be cold and relatively clear, as it was released from the reservoir located just upstream of the City.

In contrast, the Portneuf watershed lacked an appropriate site for a large storage reservoir, and decision-makers adopted a flood management strategy focused on channelization. Following especially destructive floods in the winters of 1962 and 1963, the US Corps of Engineers constructed extensive levees, which contained the river within a concrete channel and blocked river access as it passed through Pocatello (Barton 2004). Moreover, the river in Pocatello continued to reflect the accumulated impacts of upstream irrigation withdrawals and agricultural land use, exhibiting very low flows in summer and degraded water quality, including high sediment and nutrient loads, and high temperatures and low oxygen in summer (Marcarelli et al. 2010; Bechtold et al. 2012; Huang et al. 2019).

\section{SES coupling versus de-coupling trajectories}

Our analyses indicate that informational feedbacks about maintaining a riparian zone and continuous public access along the Boise River triggered a coupling trajectory. In contrast, the informational flows regarding the channelization of the Portneuf River acted as a barrier between systems, a feedback that strongly influenced the ecological integrity of the Portneuf River. This led to a disconnection between the river and the people, thereby triggering a de-coupling trajectory. The mechanisms at play here were the types of informational feedbacks created in each of the two SES (Fig. 1).

In each community, different socio-economic trends (e.g., population, employment, and business establishment) have emerged as a consequence of divergent SES trajectories. For example, if we examine the timeline of major river management decisions that took place in each river after the flood control measures were implemented (Fig. 4), we see very different types of actions that produced different informational flows between each river systems. In fact, restoring the Boise River from its previously contaminated state was largely a grass-roots community effort, and the combined informational actions of local and federal laws, such as the US Clean Water Act. In particular, in 1968, Boise passed the Greenbelt Ordinance, which prevented any development within 70 feet of the river. Currently, the Greenbelt Trail System stretches continuously for 30 miles along with the entire city of Boise, and the Greenbelt has been responsible for informing other features of cultural and aesthetic values such as bike paths, parks, and habitat for wildlife (Jaussaud 1994; Shallat et al. 2011).
In contrast, in Pocatello placement of the Portneuf River in a concrete channel topped with a chain-link fence that prevents public access (Fig. 2C, D) left little space for a "Greenbelt," and no such ordinance was established. Rather, these actions appear to have amplified the informational flows regarding the river as polluted and diminished thoughts of the river and riverside corridor as amenities to the community. Indeed, even when efforts began to surface in the 1990's and 2000's to establish a recreational corridor in the Portneuf Valley, these occurred piecemeal via the efforts of a non-profit "Greenway Foundation," rather than via an ordinance, and the concrete channel prevented the establishment of trails along that section of the river. The different series of management actions in the two rivers represent informational flows which served to tighten (in the case of Boise) or weaken (in the case of Portneuf) the linkages between systems (Fig. 4).

We argue that the flooding intervention and especially the development of the Boise Greenbelt promoted a major connection or coupling between the Boise community and the river, and the system's subsequent development on a coupled SES trajectory. This coupling trajectory promoted positive feedbacks between the social and ecological systems that led to positive SES outcomes, i.e., positive impacts on the ecological system and human well-being, such as the information concerning access to the river that reinforced the public awareness regarding the river (Fig. 4). This public awareness of the river's potential contributed to more conservation interventions, increasing the community's connection with the river, and subsequently reflected in measures of local identity, sense of place, and high levels of cultural heritage, local knowledge or relational values related to the river (Fig. 5). These then manifested in differences in the current ecological state of the river, as well as the social conditions. For example, currently, the Boise River sustains six times as many beneficial uses (6 of 8 ) as does the Portneuf River (1 of 8), including water for domestic, agricultural and industrial uses, and supports a variety of recreational activities such as tubing, swimming, and boating (Fig. 5, Supplementary material B, Table B1).

In contrast, today, the information about the beneficial uses provided by the Portneuf River in Pocatello to the local population are significantly limited. We argue that the channelization of the Portneuf River disconnected the Pocatello community from the river, and the system's subsequent development toward a de-coupled SES trajectory. The channelization promoted feedbacks between the social and ecological systems that were detrimental to the SES, such as the low information flow from local administration to locals that promoted a lack of public knowledge of the Portneuf River, leading to low public awareness and values attached from the local population (Fig. 5). These feedbacks led to detrimental SES outcomes, i.e., negative impacts on 


\begin{tabular}{|c|c|c|}
\hline A Portneuf River & $\begin{array}{l}\text { Ecological indicators } \\
\text { Beneficial uses: } \\
\checkmark \text { Agricultural/industrial } \\
\text { water supply } \\
\text { Causes of impairments: } \\
\text { - High temperatures } \\
\text { - Low flow alteration } \\
\text { - Physical substrate habitat } \\
\text { - } \text { alteration } \\
\text { - High dissolved oxygen } \\
\text { - High bacteria (Escherichia coli) } \\
\text { - High oil and grease } \\
\text { - High nitrogen. }\end{array}$ & $\begin{array}{l}\text { Social indicators } \\
\text { - } \quad \text { Population growth rate: } 0.15 \% \\
\text { - } \quad \text { Employment growth rate: }-2.51 \% \\
\text { - } \text { Household income rate last year: }-1.28 \% \\
\text { - } \text { Property value growth rate: } 0.91 \% \\
\text { - } \text { Business establishment ratio: }-1.54 \% \\
\text { - } \quad \text { Food insecurity rate: } 13.40 \% \\
\text { Ecosystem service perceptions } \\
\text { Most important } \\
\text { - } \quad \text { Food: } 55.77 \% \\
\text { - Water quality: } 50.00 \% \\
\text { - Habitat: } 58.46 \% \\
\text { - } \quad \text { Recreation: } 50.77 \% \\
\text { Meaning of the river } \\
\text { - Meaning of the river: } 34.23 \% \\
\end{array}$ \\
\hline $\mathrm{B} B$ & $\begin{array}{l}\text { Ecological indicators } \\
\text { Beneficial uses: } \\
\checkmark \text { Domestic water supply } \\
\checkmark \text { Agricultural/industrial } \\
\quad \text { water supply } \\
\checkmark \text { Primary contact recreation } \\
\checkmark \text { Secondary contact } \\
\quad \text { recreation } \\
\checkmark \text { Aesthetics } \\
\checkmark \text { Wildlife habitats } \\
\text { Causes of impairments: } \\
\text { - High temperatures } \\
\text { - Low flow alteration } \\
\text { - Physical substrate habitat } \\
\text { alteration. }\end{array}$ & 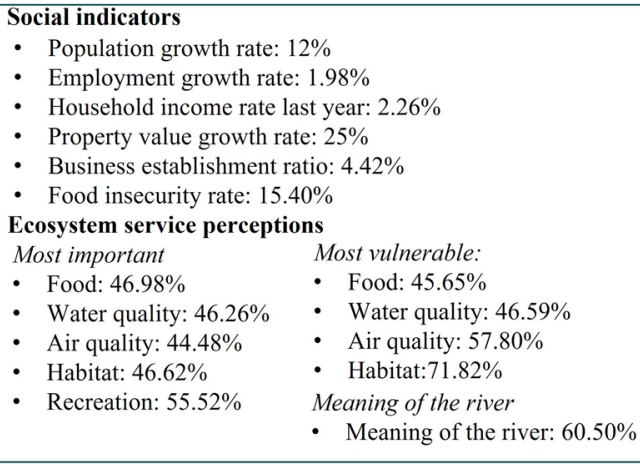 \\
\hline
\end{tabular}

Fig. 5 Summary of some indicators compiled for the (a) Portneuf social-ecological river system, and (b) Boise social-ecological river system. See supplementary material for the full list of indicators used

the ecological system and human well-being. The negative ecological impacts include degraded water quality and loss of river-riparian habitats. Access to the river was also reduced (indeed, the concrete-lined segment within the city was encompassed by a chain-link fence; Fig. 2C, D), which, along with degraded conditions, may have reinforced a lack of public awareness regarding the river. Reduced public awareness of the river's potential contributed to a lack of interventions that might have reversed the trajectory, and instead the river's degraded ecological state fed back to perpetuate the community's disconnection with the river. This is reflected in measures of local identity, sense of place, and loss of cultural heritage, local knowledge or relational values related to the river (Fig. 5). Outside of the concrete channel section, fishing and boating can occur but has been minimal in the past several decades, and advisories against swimming have been common owing to occasional high levels of bacteria. Formally, the only beneficial use currently provided is the supply for water for agricultural and industrial uses. The variety of causes of river impairments identified ( 3 times more impairments than listed for Boise River) include: high temperatures, low flow alteration, physical substrate habitat alteration, low dissolved oxygen, high sediment/siltation, high bacteria (Escherichia coli), high oil and grease, and high nitrogen (IDEQ 2017; Fig. 5; Supplementary material B, Table B1).
In terms of the social perception of ecosystem services provided by the two river systems, along the Boise River, locals perceived and recognized a high variety of services provided (Fig. 5, Supplementary material D, Table D1). For instance, Boise respondents recognized multiple recreational opportunities provided by the Boise River, including the Greenbelt, floating, fly-fishing and kayaking. Locals in Boise also considered that the Boise River had meaning for them (more than $60 \%$ of respondents), such as "symbol of life and connection with nature," and "local identity and heart of Boise", and almost 78\% expressed that they liked living near the Boise River.

Residents in Pocatello recognized the Portneuf River's benefits as the most vulnerable in the region, and simultaneously, water-related regulating ecosystem services as most important along the Portneuf River. However, only 34\% of Pocatello residents considered that the Portneuf River had meaning for them. The most frequent meanings described for the Portneuf River were "recreational and enjoyment", "natural resources" and "peaceful and spiritual values". However, it appears likely that Pocatello residents that responded in this fashion were alluding to connections to the river outside of the city, as $20 \%$ of respondents indicated that they did not like anything about living near the river, and most cited lack of water quality, pollution and the channelization (Supplementary material D, Table D1). Only 58\% 
of Pocatello residents expressed that they liked living near the Portneuf River.

We also recorded residents' participation in communityoriented activities, as a metric of linkage and identity to the city and the river area. The residents of Boise reported higher participation in community groups, voting, public affairs, and feelings of belonging to community (39\% of respondents). In the Portneuf, this response was lower only $24 \%$ reported as such. In addition, the data compiled showed that in Boise, property values tend to be higher in the areas near the river, whereas the opposite was found in Pocatello. Additionally, as of 2109 Boise had a population of 236,310 and is considered one of the most desirable places to live in the US (Sharf 2018) due to human well-being metrics (Fig. 5). In contrast, some economic and social metrics in the Portneuf showed a very different story. Pocatello had higher rates of food insecurity, lower levels of health coverage, and higher smoking and obesity prevalence compared to Boise. Contrary to Boise, in Pocatello the socio-economic indicators of population, employment and business establishment have exhibited a negative or stagnant trend (Supplementary material C, Table C1).

\section{Discussion and conclusion: the utility of considering SES trajectories to aid in "re-coupling" or maintaining coupling of SES}

We have presented contrasting case studies of two river systems that followed different SES trajectories over the last century, and demonstrated how those trajectories manifested in the current SES state and set the stage for their potential futures. Decades ago, the Portneuf River was physically disconnected from local residents, initiating a de-coupling trajectory. Currently, the river provides limited benefits to the community, and many local residents do not recognize the river as part of the city, nor do they value the benefits it does provide.

Recently, the community has initiated the first steps in efforts to "recouple" the Portneuf SES. The Portneuf River Vision (2016; see https://river.pocatello.us/) represents a multi-year effort by a coalition of stakeholders including social surveys of the community and ecological studies of the river, community dialogue, and planning. The Pocatello City Council adopted the Vision in 2017, and are currently implementing its first stages of re-connecting the Pocatello community to the river through river clean-ups and improved public access, including establishment of a water trail for boating and floating, and re-design of riverside parks to provide access and restore riparian connections. Concurrently, various efforts have been underway throughout the watershed upstream (e.g., riparian area fencing and river-floodplain restoration), as well as within the City (e.g., stormwater management) with the goal of improving the
Portneuf's water quality and overall ecological state. In Summer 2019, the new water trail was opened with a coordinated event in which over 1000 people floated down the Portneuf River, indicating growing enthusiasm in the Pocatello community for the river vision.

Efforts like the Portneuf River Vision represent a potential positive, re-coupled future for that river SES, but whether such a vision can be realized remains to be seen. The decisions of the past have created ecological circumstances that make it challenging to achieve a re-coupled river SES state for the Portneuf River. River ecological restoration can be conceptualized as "re-expression of habitat capacity," but that capacity is constrained by changes that may have been wrought and that may not be reversible (Ebersole et al. 1997). Extending this concept, the history of a river SES may also constrain its potential futures, such that key decisions in the histories of river-associated SES, like removing most flow in summer for irrigation or channelizing a river like the Portneuf, may limit the futures that are possible. Moreover, a community's cultural connections to a river, or "relational values" (Chan et al. 2016), may also influence futures. For instance, if losing contact with the Portneuf River in Pocatello has resulted in the loss of rivercentered local identity, cultural heritage or local ecological knowledge, these could limit the potential for river SES recoupling. Examples from the broader SES literature (e.g., Kirsch, 2001; Adger et al. 2013; Fernández-Giménez et al. 2017) suggest that culture is intertwined with occupational and place identity, and with access to, use and stewardship of particular resources. If people lose this access (e.g., via forced resettlement or environmental disaster), or voluntarily abandon places or livelihoods (e.g., rural-urban migration), then place- and livelihood-based cultural knowledge and identity are diminished. Such changes in SES potential capacity may not be reversible. On the other hand, when it comes to river SES, the odds of successful re-coupling may be improved if restoration of river habitat conditions is purposefully linked to efforts aimed at restoration of a community's relational values associated with its river. This is an outlook that leaders of the Portneuf River Vision have adopted (Hannah Sanger, City of Pocatello, personal communication), and is manifested in their efforts to improve access to and appreciation of the river, and by creating networks of people brought together by their interest in the river and commitment to addressing its challenges.

The Boise River SES is on a coupled trajectory, but it also faces challenges in terms of the maintenance of this connected state. Because of flood control management decisions made decades ago, the city was able to maintain a more natural river channel and riparian zone, which subsequently allowed river access and the establishment of the Boise Greenbelt. Both play a crucial role in the coupling trajectory that promoted positive feedbacks and positive outcomes 
for the river ecosystem, the community's relationships with the river, and human well-being. That said, maintaining this coupled state is likely to pose its own challenges. The Boise region is presently home to Idaho's largest cities (Boise, Nampa, and Meridian; combined population of $\sim 400,000$ ), and the Boise metropolitan area is one of the fastest growing in America, with a 120\% population increase between 1990 and 2015 (Sharf 2018). Commercial and residential development is projected to increase water demand $250-350 \%$. Rapid urban expansion, coupled with climate change, has affected the quality and quantity of water supply, emerging as one of the major challenges in the area (Han et al. 2017; Quintas-Soriano et al. 2018; Narducci et al. 2019). In the face of these changes, maintaining the ecological and aesthetic conditions of the Boise River and its Greenbelt that have made it such a desirable corridor for recreation and various community uses may become more difficult. The numbers of people using the river could itself become part of the challenge. The number of residents floating the river through Boise has increased by $\sim 50 \%$ in the past two years alone. Similarly, the social character of the community is also likely to change, and values associated with the river, intrinsic or relational, may also be expected to change. For example, there have been recent disputes among citizens over proposed development of high-rise (and high-cost) apartments and parking garages along the Greenbelt, which some argue would alter its aesthetic character and displace lower-income residents who are deeply connected to the area. In any case, the shifting social and ecological backdrop for the Boise River and its community will pose challenges for maintaining healthy connections between them. To maintain a coupled SES, planners and managers associated with the Boise River SES will not be able to rely on "business as usual," but will need proactive, purposeful actions that nurture key relationships between the river and the community.

\section{Advancing sustainability science by incorporating coupling and de-coupling trajectories}

Our case studies focused on river SES, but more generally, the purpose of our conceptual framework is to more effectively address two major sustainability challenges: (1) in coupled SES, maintaining linkages between the social and ecological systems, and (2) "re-coupling", i.e., transforming a de-coupled system to a coupled system. SES are not only shaped by complex interactions between people and nature, but also by feedbacks and drivers that can are highly variable in space and over time (Thiault et al. 2018). Our conceptual framework views a SES as occurring on a trajectory towards more or less "coupled-ness," and we demonstrate how specific management interventions, over time, can help to maintain a SES on a given trajectory or shift it into a different trajectory.
The proposed framework and the novel concepts of SES trajectories can help to advance the understanding of SES and specifically lead the next steps to advance the current state of Sustainability Science. Our proposed framework will not only provide the skeleton and frame to advance in the science of SES analysis, but it will also allow the specific evaluation and characterization of coupling and de-coupling. This study advances in the understanding of key concepts in sustainability science such as coupling and decoupling by providing definitions, but also incorporates a quantitative approach for their application in other case studies and multiple contexts. By incorporating our framework into community discussions and decision-making, policymakers and community leaders may be able to conceptualize the current state and trajectory of their SES, identify specific actions in the past that led to the current state and trajectory, and identify immediate actions to reinforce or shift the trajectory. In addition, we demonstrate how widely available quantitative measures can be used as metrics of coupled-ness and be quantitative applied by the new equation proposed. For our river SES case studies, we identify several quantifiable measures relevant to river systems, for the different SES components, which serve as "indicators". Identifying and tracking indicators of coupled-ness in any given SES may enable decision-makers to better understand the outcomes of given management decisions and allow adaptive management over time.

\section{Pending tasks for future research of SES trajectories}

The main goal of this paper was to present a conceptual framework for SES trajectories, using a two-site case study comparison approach. We compiled quantitative data at a single point in time, to demonstrate what types of data could be used as indicators of social and ecological conditions. The next logical step is the development of a quantitative analytical approach that is linked to our SES conceptual framework and with the potential for evaluating the level of social-ecological coupling and de-coupling trajectories. Here we propose such an approach, one that would require time-series data of social and ecological indicators, and ideally, multiple case study sites. Although we did not apply it to our case study because of insufficient data, we anticipate that the following equation can guide future efforts to advance the empirical analysis of SES trajectories.

$D=\left(\sum_{i=1}^{n} \sum_{j=1}^{m}\left|\operatorname{cor}_{1: T}\left(e_{i}, s_{j}\right)\right| / n * m\right) * 100$

where $D$ is the percentage of coupling/de-coupling, $n$ and $m$ is the total number of ecological and social indicators, respectively, $\operatorname{cor}_{1: T}$ represents the correlation from time 1 to $\mathrm{T}$ between ecological indicator $e_{i}$ and social indicator $s_{j}$. 
The resulting index, $\mathrm{D}$, is a number that ranges from 0 to 100 , and can be interpreted as an indicator of the level of coupling and de-coupling. Ecological and social indicators are integrated in absolute values but must be interpreted from a qualitative perspective. Values closer to 0 indicate a scenario of the weak correlation between the ecological and social systems, and values closer to 100 indicate a higher correlation between the social and ecological systems. A coupling or decoupling trajectory is thus defined by the strength and direction of correlation between social and ecological indicators. However, note that the correlation between both indicators should be interpreted in qualitative terms depending on the type of informational flows in both systems, i.e., indicators that define a good or bad status of ecosystem and society. Thus, a coupling trajectory would occur in a strong correlation scenario when indicators of the ecological systems and the social systems suggest beneficial SES outcomes (i.e., ecosystem services and human well-being). An example of this trajectory may occur when positive indicators of the health of the river and society are positive and strongly correlated. On the contrary, a de-coupling trajectory is defined in a strong correlation scenario when indicators of the ecological and the social systems suggest unfavorable SES outcomes (i.e., ecosystem services and human well-being). For instance, this trajectory may occur when negative indicators of the health of river and society are strongly correlated. Finally, a weak correlation between ecological and social indicators reflects a transitional trajectory where there is a lack of feedback loops and therefore a lack of informational flows between systems. This scenario may evolve into coupling and de-coupling trajectories over time.

Supplementary Information The online version contains supplementary material available at https://doi.org/10.1007/s11625-021-01048-0.

Acknowledgements This research was made possible by the NSF Idaho EPSCoR Program and by the National Science Foundation under award number IIA-1301792. We certify that the Institutional Review Board (IRB) for the Protection of Human Participants at Idaho State University has approved the IRB protocol with permit number IRB-FY2016-371.

Funding Open Access funding provided thanks to the CRUE-CSIC agreement with Springer Nature.

Open Access This article is licensed under a Creative Commons Attribution 4.0 International License, which permits use, sharing, adaptation, distribution and reproduction in any medium or format, as long as you give appropriate credit to the original author(s) and the source, provide a link to the Creative Commons licence, and indicate if changes were made. The images or other third party material in this article are included in the article's Creative Commons licence, unless indicated otherwise in a credit line to the material. If material is not included in the article's Creative Commons licence and your intended use is not permitted by statutory regulation or exceeds the permitted use, you will need to obtain permission directly from the copyright holder. To view a copy of this licence, visit http://creativecommons.org/licenses/by/4.0/.

\section{References}

Adger WN, Barnett J, Brown K et al (2013) Cultural dimensions of climate change impacts and adaptation. Nat Clim Chang 3:112-117. https://doi.org/10.1038/nclimate1666

Alessa L, Kliskey A, Brown G (2008) Social-ecological hotspots mapping: A spatial approach for identifying coupled social-ecological space. Landsc Urban Plan 85:27-39. https://doi.org/10.1016/j. landurbplan.2007.09.007

Armitage D, Berkes F, Doubleday N (2007) Adaptive Co-management collaboration, learning, and multi-level governance. UBC Press, Vancouver

Barton GJ (2004) Surface- and ground-water relations on the Portneuf River, and temporal changes in ground-water levels in the Portneuf Valley, Caribou and Bannock Counties, Idaho. U.S. Geological Survey Scientific Investigations Report 2004-5170,p 50

Bauch CT, Sigdel R, Pharaon J, Anand M (2016) Early warning signals of regime shifts in coupled human-environment systems. PNAS 113:14560-14567. https://doi.org/10.1073/pnas.1604978113

Bechtold HA, Marcarelli AM, Baxter CV, Inouye RS (2012) Effects of $\mathrm{N}, \mathrm{P}$, and organic carbon on stream biofilm nutrient limitation and uptake in a semi-arid watershed. Limnol Oceanogr 57:1544-1554. https://doi.org/10.4319/lo.2012.57.5.1544

Benke AC (1990) A perspective on America's vanishing streams. J N Am Benthol Soc. https://doi.org/10.2307/1467936

Berkes F, Folke C (2000) Linking social and ecological systems management practices and social mechanisms building resilience. Ecology and conservation. Cambridge University Press, Cambridge

Biggs R, Schlüter M, Biggs D et al (2012) Toward principles for enhancing the resilience of ecosystem services. Annu Rev Environ Resour 37:421-448. https://doi.org/10.1146/annurev-envir on-051211-123836

Chan KMA, Balvanera P, Benessaiah K et al (2016) Opinion: Why protect nature? Rethinking values and the environment. PNAS 113:1462-1465. https://doi.org/10.1073/pnas.1525002113

Chapin FS, Carpenter SR, Kofinas GP et al (2010) Ecosystem stewardship: sustainability strategies for a rapidly changing planet. Trends Ecol Evol 25:241-249. https://doi.org/10.1016/j.tree. 2009.10.008

Chen J, John R, Zhang Y et al (2015) Divergences of two coupled human and natural systems on the Mongolian Plateau. Bioscience 65:559-570. https://doi.org/10.1093/biosci/biv050

Döll P, Fiedler K, Zhang J (2009) Global-scale analysis of river flow alterations due to water withdrawals and reservoirs. Hydrol Earth Syst Sci 13:2413-2432. https://doi.org/10.5194/ hess-13-2413-2009

Dunham JB, Angermeier PL, Crausbay SD et al (2018) Rivers are social-ecological systems: time to integrate human dimensions into riverscape ecology and management. Wires Water 5:e1291. https://doi.org/10.1002/wat2.1291

Ebersole JL, Liss WJ, Frissell C (1997) FORUM: restoration of stream habitats in the Western United States: restoration as reexpression of habitat capacity. Environ Manag 21:1-14. https://doi.org/10. 1007/s002679900001

Entwisle B, Stern PC (2005) Population, land use and environment: Research directions. Washington, DC: National Academies Press

Fernández-Giménez ME, Venable NH, Angerer J et al (2017) Exploring linked ecological and cultural tipping points in Mongolia. 
Anthropocene 17:46-69. https://doi.org/10.1016/j.ancene.2017. 01.003

Fischer-Kowalski M, Weisz H (2016) The archipelago of social ecology and the island of the Vienna school. In: Haberl H, FischerKowalski M, Krausmann F, Winiwarter V (eds) Social ecology: society-nature relations across time and Space. Springer International Publishing, Cham, pp 3-28

Foley JA, DeFries R, Asner GP et al (2005) Global consequences of land use. Science 309:570-574. https://doi.org/10.1126/science. 1111772

Folke C (2006) Resilience: The emergence of a perspective for socialecological systems analyses. Glob Environ Change 16:253-267. https://doi.org/10.1016/j.gloenvcha.2006.04.002

Folke C, Hahn T, Olsson P, Norberg J (2005) Adaptive governance of social-ecological systems. Annu Rev Environ Resour 30:441-473. https://doi.org/10.1146/annurev.energy.30.050504.144511

Folke C, Carpenter S, Walker B et al (2010) Resilience thinking: integrating resilience, adaptability and transformability. Ecol Soc. https://doi.org/10.5751/ES-03610-150420

Gunderson L, Cosens B, Chaffin BC (2018) Trajectories of change in regional-scale social-ecological water systems. In: Cosens B, Gunderson L (eds) Practical panarchy for adaptive water governance: linking law to social-ecological resilience. Springer International Publishing, Cham, pp 229-241

Haines-Young R, Potschin M (2010) The links between biodiversity, ecosystem services and human well-being. Ecosystem ecology: a new synthesis. Cambridge University Press, Cambridge

Han B, Benner SG, Bolte JP et al (2017) Coupling biophysical processes and water rights to simulate spatially distributed water use in an intensively managed hydrologic system. Hydrol Earth Syst Sci 21:3671-3685. https://doi.org/10.5194/hess-21-3671-2017

Hand BK, Flint CG, Frissell CA et al (2018) A social-ecological perspective for riverscape management in the Columbia River Basin. Front Ecol Environ 16:S23-S33. https://doi.org/10.1002/fee.1752

Holzer JM, Adamescu CM, Cazacu C et al (2019) Evaluating transdisciplinary science to open research-implementation spaces in European social-ecological systems. Biol Cons 238:108228. https:// doi.org/10.1016/j.biocon.2019.108228

Hoole A, Berkes F (2010) Breaking down fences: Recoupling socialecological systems for biodiversity conservation in Namibia. Geoforum 41:304-317. https://doi.org/10.1016/j.geoforum.2009.10. 009

Huang L, Liao FH, Lohse KA et al (2019) Land conservation can mitigate freshwater ecosystem services degradation due to climate change in a semiarid catchment: the case of the Portneuf River catchment, Idaho, USA. Sci Total Environ 651:1796-1809. https://doi.org/10.1016/j.scitotenv.2018.09.260

IDEQ (2017) Integrated Report 2017. State of Idaho. Department of Environmental Quality. https://www.deq.idaho.gov/water-quali ty/surface-water/monitoring-and-assessment/. Accessed $28 \mathrm{Sept}$ 2021

Jaussaud RM (1994) When the river rises: flood control on the Boise River, 1943-1985 Susan M Stacy. Public Hist 16(3):71-73. https://doi.org/10.2307/3378508

Kirsch S (2001) Lost worlds: environmental disaster, "Culture Loss", and the law. Curr Anthropol 42:167-198. https://doi.org/10.1086/ 320006

Lambin EF, Meyfroidt P (2011) Global land use change, economic globalization, and the looming land scarcity. PNAS. https://doi. org/10.1073/pnas.1100480108

Link PK, Phoenix EC (1994) Rocks rails and trails, edition, 1st edn. Idaho State University Press, Pocatello

Liu J, Dietz T, Carpenter SR et al (2007a) Complexity of coupled human and natural systems. Science 317:1513-1516. https://doi. org/10.1126/science.1144004
Liu J, Dietz T, Carpenter SR et al (2007b) Coupled human and natural systems. Ambio 36:639-649. https://doi.org/10.1579/00447447(2007)36[639:CHANS]2.0.CO;2

Locatelli B, Lavorel S, Sloan S et al (2017) Characteristic trajectories of ecosystem services in mountains. Front Ecol Environ 15:150 159. https://doi.org/10.1002/fee. 1470

MacGregor CL (1999) Founding Community in Boise, Idaho, 1882 1910. Dissertation for PhD. University of New Mexico

Marcarelli AM, Kirk RWV, Baxter CV (2010) Predicting effects of hydrologic alteration and climate change on ecosystem metabolism in a western U.S. river. Ecol Appl 20:2081-2088. https://doi. org/10.1890/09-2364.1

Mathias J-D, Anderies JM, Baggio J et al (2020) Exploring non-linear transition pathways in social-ecological systems. Sci Rep 10:1-12. https://doi.org/10.1038/s41598-020-59713-w

Meyer R, Turner BL II (1994) Changes in Land use and land cover: a global perspective. In: Ch M (ed) Trends in ecology and evolution. Cambridge University Press, Cambridge, p 537. https://doi.org/10. 1016/S0169-5347(00)89086-2 (ISBN 0521470854 )

Minshall GW, Andrews DA (1973) An ecological investigation of the Portneuf River, Idaho: a semiarid-land stream subjected to pollution. Freshw Biol 3:1-30. https://doi.org/10.1111/j.1365-2427. 1973.tb00059.x

Murphy RF, Murphy Y (1960) Shoshone-Bannock subsistence and society. University of California Anthropological Records. Vol 16, No. 7, pp 293-338. United States. ISBN 101506185266

Narducci J, Quintas-Soriano C, Castro A et al (2019) Implications of urban growth and farmland loss for ecosystem services in the western United States. Land Use Policy 86:1-11. https://doi.org/ 10.1016/j.landusepol.2019.04.029

Norberg J, Cumming G (2008) Complexity theory for a sustainable future. Columbia University Press, New York

Ostrom E (2009) A general framework for analyzing sustainability of social-ecological systems. Science 325:419-422. https://doi.org/ 10.1126/science. 1172133

Poff NL, Olden JD, Merritt DM, Pepin DM (2007) Homogenization of regional river dynamics by dams and global biodiversity implications. Proc Natl Acad Sci USA 104:5732. https://doi.org/10.1073/ pnas.0609812104

Postel S, Richter B (2012) Rivers for life: managing water for people and nature. Island Press, Washington

Pulver S, Ulibarri N, Sobocinski K et al (2018) Frontiers in socio-environmental research: components, connections, scale, and context. Ecol Soc. https://doi.org/10.5751/ES-10280-230323

Quintas-Soriano C, Brandt J, Running K et al (2018) Social-ecological systems influence ecosystem service perception: a Programme on Ecosystem Change and Society (PECS) analysis. Ecol Soc. https:// doi.org/10.5751/ES-10226-230303

Quintas-Soriano C, Gibson DM, Brandt JS et al (2021) An interdisciplinary assessment of private conservation areas in the Western United States. Ambio 50:150-162. https://doi.org/10.1007/ s13280-020-01323-x

Reyers B, Selomane O (2018) Social-ecological systems approaches revealing and navigating the complex trade-offs of sustainable development. Book ecosystem services and poverty alleviation. Routledge, London, p 16

Rist L, Felton A, Nyström M et al (2014) Applying resilience thinking to production ecosystems. Ecosphere 5:73. https://doi.org/10. 1890/ES13-00330.1

Santos-Martín F, González García-Mon B, González J et al (2019) Identifying past social-ecological thresholds to understand longterm temporal dynamics in Spain. Ecol Soc. https://doi.org/10. 5751/ES-10734-240210

Schmitz MF, Herrero-Jáuregui C, Arnaiz-Schmitz C et al (2017) Evaluating the role of a protected area on hedgerow conservation: the 
case of a spanish cultural landscape. Land Degrad Dev 28:833842. https://doi.org/10.1002/ldr.2659

Shallat T, Burns, B, Burke L (2011) Growing Closer: Density and Sprawl in the Boise Valley. Shallat (editor); Burns (editor); and Burke (editor), Faculty \& Staff Authored Books. 309. http://schol arworks.boisestate.edu/fac_books/309

Sharf S (2018) Full List: America's Fastest-Growing Cities 2018. Forbes. https://www.forbes.com/sites/samanthasharf/2018/02/ 28/americas-fastest-growing-cities-2018/? sh $=2 \mathrm{~cd} 023 \mathrm{~b} 745 \mathrm{dc}$. Accessed 28 Sept 2021

Thiault L, Marshall P, Gelcich S et al (2018) Space and time matter in social-ecological vulnerability assessments. Mar Policy 88:213221. https://doi.org/10.1016/j.marpol.2017.11.027

Torgersen CE, Le Pichon C, Fullerton AH, Dugdale SJ, Duda JJ, Giovannini $\mathrm{F}$, Tales E, Belliard J, Branco P, Bergeron N, Roy ML, Tonolla D, Lamouroux N, Capra H, Baxter CV. In Press. Riverscape approaches in practice: perspectives and applications. Biol Rev

US Bureau of Census (2016) Bureau of Economic Analysis (2016) U.S. Department of Commerce. https://www.bea.gov/ https://data. census.gov/cedsci/. Accessed 28 Sept 2021
Walker B, Salt D (2006) Resilience thinking. Island Press, Washington Walker B, Holling CS, Carpenter S, Kinzig A (2004) Resilience, adaptability and transformability in social-ecological systems. Ecol Soc. https://doi.org/10.5751/ES-00650-090205

Wang S, Fu B, Zhao W et al (2018) Structure, function, and dynamic mechanisms of coupled human-natural systems. Curr Opin Environ Sustainy 33:87-91. https://doi.org/10.1016/j.cosust.2018.05. 002

Yeakley JA, Ervin D, Chang H et al (2016) Ecosystem services of streams and rivers. River science. John Wiley \& Sons Ltd, New Jersey, pp 335-352

Publisher's Note Springer Nature remains neutral with regard to jurisdictional claims in published maps and institutional affiliations. 